\title{
ICONOGRAPHY OF GOIANA: a participative approach in the search for a shared design project
}

\author{
Virginia Cavalcanti ${ }^{1, a}$, Felipe Soares $^{2}$, Ana Andrade $^{3}$, Tibério Tabosa $^{4}$ \\ ${ }^{1}$ Laboratório de Design O Imaginário da UFPE, Recife, Pernambuco, Brasil \\ ${ }^{2}$ Laboratório de Design O Imaginário da UFPE, Recife, Pernambuco, Brasil \\ ${ }^{3}$ Laboratório de Design O Imaginário da UFPE, Recife, Pernambuco, Brasil \\ ${ }^{4}$ Laboratório de Design O Imaginário da UFPE, Recife, Pernambuco, Brasil
}

\begin{abstract}
Given the current paradigms and complexity of the contemporary context together with the support of new technologies and communication, alternative ways to build, produce, deliver/distribute projects and artifacts have arisen. These new formats discuss, among other issues, how authorship is configured and gains recognition. This phenomenon can be identified in the design field by examining approaches such as participatory design, collaborative design and open design. This article describes the iconography project ${ }^{a}$, which used the premises of participatory design and was developed for the town of Goiana, Pernambuco. It arose from a request from SEBRAE PE and Goiana Town Hall. The research methods were of an exploratory and qualitative character. The former included a review of the literature, a search for documents and the conduct of interviews; and the latter gave value to the content of systematized information and the oral history of the town. Both benefitted from the constant and intensive involvement of the community and local participants. The results, photographic records and graphical elements for each of the icons, confirm how important it is that contractors, the various segments of the local community and representatives of the Town Hall take part as this ensures the quality of the final project.
\end{abstract}

Keywords. Iconography, Participative Design, design methods.

\footnotetext{
a Iconography is the set of icons on a particular theme; in this case, the town of Goiana, PE. An icon, in a broad sense, is an image that because of its likeness represents something else, such as a heritage building, an event, a scenario or a cultural phenomenon. Icons are unique and singular and identifying them with their place of origin gives them their symbolic strength and value as a reference.
}

\section{Introduction}

In order to tackle complex problems, it has been necessary to share ideas and encourage alternative forms of coexistence, which have repercussions, namely solutions that bear the stamp of being social innovations. The emergence of several practices associated with participatory production in the area of creation and innovation is a characteristic of contemporary production relations, which are strongly grounded on the dynamics of social cooperation. (FERREIRA, 2011)

Conceiving new products and services reflects the growing need to broaden the forms of interaction and

\footnotetext{
a cavalcanti.virginia@gmail.com
}

therefore the demand for a combination of competencies, not only of designers, but of all those involved in the process, thus increasing the complexity of design (FONTANA et al, 2011). Among the collaborative approaches in the ambit of design are Participatory Design and Open Design.

Fontana defines collaboration in design as follows:

"It is a reciprocal effort between people of equal or different areas of knowledge, whether or not they are physically separated, with the common goal of finding a solution that satisfies all stakeholders. This can happen by sharing information and responsibilities, organizing tasks and resources, managing multiple perspectives, and 
creating a shared understanding in a Design process. Collaboration aims to produce a consistent and complete product and/or service by using a wide variety of sources of information with a certain degree of coordinating the various activities implemented. This process depends on the relationship between the actors involved, mutual trust and the dedication of each party "(Fontana et al 2001, page 4)

The user's participation in the development process is not a novelty, especially when this is about seeking information with regard to the design problem. However, the user as an active participant in the creative process and as a party to the process of development and validation has been the object of recent study. Sanders (2008), on making the parallel between the user-centered design approach and participatory design, makes it clear that in the first situation the user is investigated and observed, but does not suggest design solutions; in participatory design, on the other hand, users and designers work together throughout the process.

Del Gaudio 2014 points out some characteristics relevant to understanding participatory design, namely: it is directed mainly to designers who wish to act in a problematic situation by means of the actions of the people who are affected by the situation; it Is prompted by Participative Democracy; and the decision-making process is decentralized so that sectors of society can participate in it. In addition, users are considered both because of their skills and implicit knowledge and in relation to the context, and it being recognized that there is a collective intelligence. The use of people's knowledge and the possibility of undertaking the project in the environment where it is to be implemented are also important characteristics. Three aspects are pointed out as fundamental for conducting Participatory Design: equity, open discussion and a commitment to participate.

Thus, it is possible to think of a new conception of processes which are less verticalized and closed because new forms of production and concepts of openness are inserted into it, thereby turning design "into a tool of social innovation so that communities and society may invent new rules, [.. .] "(CABEZA et.al 2014 p.57). New collaborative production centers emerge and making projects with their "open codes" available demonstrate the attempt to make the design process more collaborative, open, and consequently more accessible.

This article describes the iconography project developed for the town of Goiana, Pernambuco, based on a request from SEBRAE PE and Goiana Town Hall, and which was grounded on the premises of participatory design. As to research methods, there was an exploratory method, which included a review of the literature, a survey of documents and the conduct of interviews; and a qualitative one, which gave value to the content of systematized information and the oral history of the town. These benefitted from the constant and intensive involvement of the community and local participants

The project considered that, in the scenarios defined as dynamic, fluid, mutant and complex, dealing with intangible attributes of cultural artifacts is a challenge for design that reflects the necessary interaction with other areas, which comprise actions that are interdisciplinary (FONTANA et al, 2011). It is in the interdisciplinary context that the complexity of undertaking design increases and, consequently, design becomes a multi-actor task. (PIRAINEN et al, 2009)

In the framework of these social relations, it is also important to consider that, in participatory practices, time issues must be negotiated. Del Gaudio et al (2014) present a suggestion about what needs to be considered in order to increase the success rate in community interventions: the local rhythm, the time of change and the pace of participation. According to the author "each actor of a project follows a set of temporal norms which are determined starting from the institutional environment of belonging."

In participatory projects, cultural and behavioral barriers spring up that must be overcome by the team. Another aspect that must be observed is the need to know and decode a territory ${ }^{\mathrm{b}}$, which, as Barroso recalls, demands an immersion in the collective unconscious so as to identify what he calls the original meaning (BARROSO, 2007). Projects of this nature require a participatory approach, so that the actors involved in the process take possession of the final result and make it legitimate.

\section{Development}

The project of the iconography of Goiana was made at the request of SebraePE to (omitted for the purposes of blind review) based on a need of the Goiana Town Hall, the purpose of which was to generate graphical and conceptual support that could be absorbed by society, as elements of adding value to products and services that are developed locally. The result of the project will be made available via SEBRAE in various formats so that craft-workers, artisans, artists, producers, among many other local actors, may use these images in their products and services.

(Omitted for the purposes of blind review), linked to (omitted for the purposes of blind review) and (omitted for the purposes of blind review), consists of professionals, teachers and students from various fields of knowledge, and who focus on design as an instrument for environmental, economic and social sustainability. Its mission is to seek solutions based on research committed to sustainable development by offering products and design services to society.

Representatives of Sebrae-PE, Goiana Town Hall, craft and trade associations, as well as artists of different languages took part in the project; and who, in this case, are regarded as potential users of the iconography.

\footnotetext{
${ }^{b}$ According to Barroso (2007) territories must be understood beyond physical or political barriers, and thus encompass "spaces of living together and of individual and collective experiences, which define ways of being and living of its population, whose forms of expression and representation, with their codes, norms, values, procedures and behaviors define what we can call cultural identity "
} 


\subsection{Local context - Goiana, Pernambuco}

The historical, social and economic importance of the town can be recognized because there is a river port, which has a canal that was built for small and medium vessels, that lies about nine kilometers from the coast, thus enabling there to be an intense flow of goods and exchange of people and knowledge.

The industrial sector in Goiana is recognized as a producer of cement, paper and cellulose and has been receiving massive investments, particularly in the Automotive, Pharmaceutical, Hemoderivative and Biotechnology Poles and for producing Flat Glass. As to the town's traditional products, it is the largest producer in the State of fish and the second largest of sugar cane and coconut.

Goiana has a rich number of historical and cultural heritage items, nine of which have been listed by IPHAN (Institute of National Historic and Artistic Heritage) since 1938, and there are currently two other heritage items that are in the final stages of being regulated. Its coastline is twelve kilometers long, and is home to a diversity of ecosystems and special cultural manifestations due to their European, African and indigenous ancestry.

The natural exuberance, the wealth of history and culture in Goiana fill local people with pride and being made aware of this arouses visitors' interest. The architecture of its churches and houses still brings to mind the settings of prestige and power brought about when the sugar industry was at its peak.

\subsection{The Iconography Project}

The project took as a base the premises of participatory design, which includes understanding the context and its actors, and recognizing that these actors possess collective intelligence about the history and representations of the locality and that their commitment to participating in the project would be key to achieving good results.

Therefore, the construction of Goiana's iconography took into consideration Panofsky's path of interpretation which, in addition to the artistic field, includes "everyday experiences". (Panofsky apud Bohnsack, 2007). The clues for recognizing images are anchored in their recurrence, i.e., in their repetition in everyday life; in the pregnancy or adhesions that reverberate in their perpetuation in various supports and in their circularity, that is to say, in their capacity to transit in various environments such as artistic, marketing, informative advertising markets. (Iconografia Alagoana, 2001).

As research methods, the project adopted both an exploratory character, including a review of the literature, a survey of documents and the conduct of interviews; and a qualitative one, by giving value to the content of systematized information and the oral history of the locality. Both benefitted from the constant and intensive involvement of the community and local actors.
The methodological strategies outlined were as follows:

\section{Research and awareness-raising}

1. Bibliographic and document surveys using sources of research reports, documents, websites and collections of photographs related to the town, such as: Fundarpe; Gilberto Freyre Foundation; Fundaj; Goiana Town Hall; Industrial feasibility studies (Hemobrás and Fiat); IPHAN; FIDEM / CONDEPE;

2. Analysis and synthesis of the information in order to compile a montage panel of images that has the following categories: churches, gastronomy, ethnics, economy, sugar plantations, landmarks, handicrafts, urban sites, cultural manifestations, heritage buildings and tourism;

3. Raising the awareness of society and local actors and holding meetings with: plastic artists, poets, writers, managers of heritage sites, craft-workers, teachers, municipal managers, cultural producers, traders, historians, photographers, local artists, as well as guides, operators and entrepreneurs of the tourism sector;

4. Data processing, evaluation and first consolidation of the sampling of images with icone potential;

5. Field surveys: interviews with specialists and representatives of the site, records of rural and urban images; and complementary bibliographic research studies.

6. Re-evaluating the sample by selecting the references obtained in the field research;

\section{Graphical language and the icon project}

7. Defining the premises of the graphical language;

8. Developing each of the icons based on synthesizing sets of images;

9. Reorganizing and defining the synthesis categories of the town's iconography;

\section{Validation and Empowerment}

10. Validating the icons with the participants, by considering the representativeness, meaning and collective acceptance of the categories and set of icons developed.

\subsubsection{Research and Awareness-raising}

First of all, bibliographical and documentary searches that included specific literary and scientific works about the town were carried out.

The synthesis of all the material researched generated a large semantic panel ${ }^{c}$ that was organized according to the following categories: churches, gastronomy, ethnics, sugar plantations, landmarks, handicrafts, urban sites, cultural events, heritage buildings and tourism.

\footnotetext{
c The Semantic Panel is a type of visual reference framework for certain aspects of the project, such as colors, shapes, textures, concepts, scenarios, etc.
}

Semantics is concerned with the study of meaning. 
Once the panel was formatted, the first major challenge was to establish a dialogue with the actors involved. To begin the dialogue with the community, a first meeting was held to clarify the meaning of the iconography project, its scope and usefulness, and at which the importance of the community engaging in the project was emphasized in order for the results to be successful. The meeting was attended by artists, craftworkers, teachers, municipal managers, cultural producers, traders, historians, photographers, guides and tour operators; in addition to representatives from Goiana Town Hall, SEBRAE PE and the Pernambuco Design Center - CPD, a partner in the administration of the project.

At the second meeting, with the same participants, the methodology of the project was presented and validated. That was also when the semantic panels, their categories and elements, and potential of representativeness as cultural references of the city were exhibited and discussed. The dynamics were set up as follows: after being organized into small groups and in receipt of the panel of images, the participants were encouraged to comment on the images of each category and their importance, and to suggest what icons to include/exclude, thereby contributing to validating and/or complementing the material. The discussions consolidated the groups' choices and pointed to the need for further research.
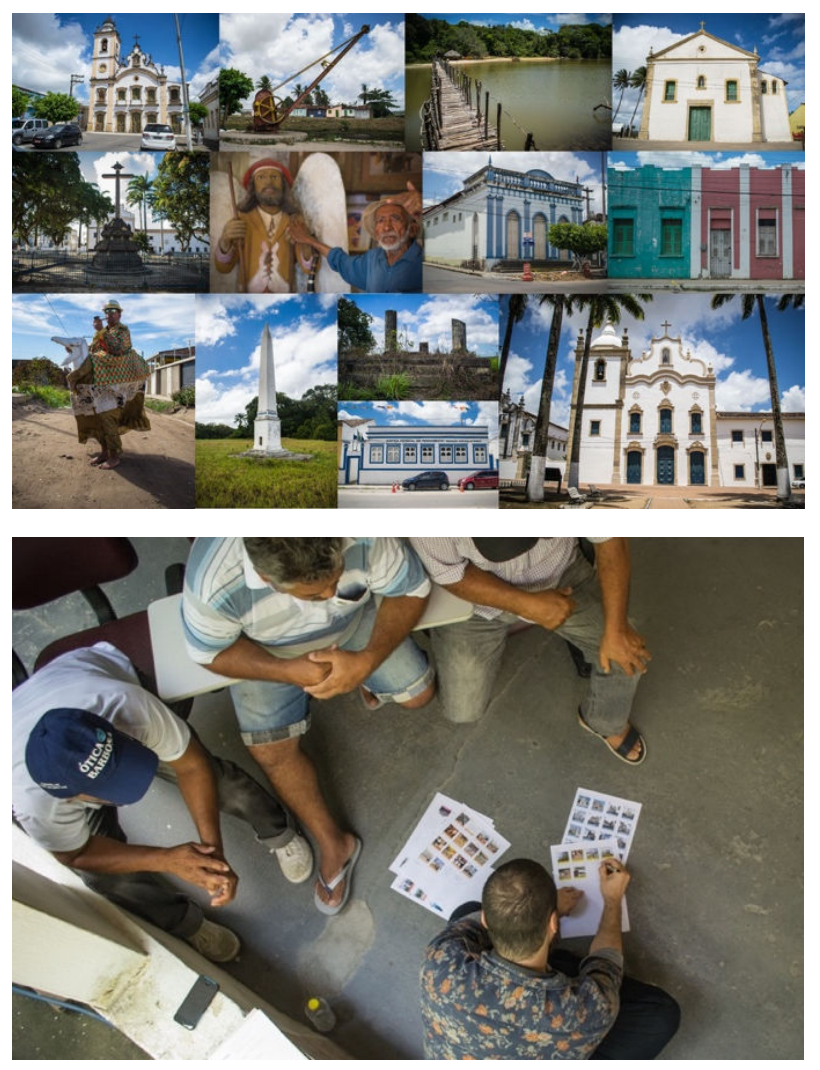

Figure 1 and 2. Panel of references for developing the icons and dynamics with semantic panels. Source: (omitted for blind review), 2016

The incidence of the responses enabled recognition of what sampling of images recurred most and which had the potential to be icons. The criterion for selection was the principles of recurrence, that is, their repetition in everyday life, their pregnancy or degree of adherence that allows them to be perpetuated in various supports and for their circularity to be determined. This reveals their ability to transit in various environments, namely artistic, marketing, advertising and other environments.

These results have given rise to new complementary research studies, which, for example, involve bibliographical research, field visits, interviews with specialists and other actors of the cultural environment, as well as taking photographic images in the town's rural and urban areas. The reorganization of the categories generated a new proposal that served as a guide for developing the icons: Architectonic Heritage (Churches, urban site and heritage buildings), the Natural Environment and Cultural Manifestations.

In order to increase the participation of the local community, the new semantic panel was presented to the participants so that they could complement and critique it.

\subsubsection{Graphical Language and Project of the Icons}

The definition of a single language for developing the icons reinforced the recognition and communication of the whole set. To do this, a clear and consistent system for creating the icons had to be developed.

Therefore, the project considered the arguments of semiotics, with concepts and definitions taken from Peirce, who considers the sign or representative as anything that replaces something else, it being represented to someone, under given aspects and to a given extent. (PIGNATARI, 2002). To boost this thinking, Niemeyer (2009: 25) states "The sign has the role of mediating between something that is absent and a present interpreter." For the iconography project, these concepts are adequate to build the consistency of communication with a view to engaging on participatory design.

In the project, the language was influenced mainly by the colonial architecture which is still very much in evidence all over the town and mainly in the churches. Based on the representation of the architectonic drawings, special attention was paid to the frontal views which when their outlines are made more definite reinforce the geometrical appeal in the two-dimensional plane. Making use of lines with different thicknesses enables volume and depth to be expressed twodimensionally.

During the development of the graphical syntheses icons -, the multiple images of each reference were used, including the reports collected during the interviews with the participants and residents; and the images of greatest representativeness, such as photographs taken in loco, drawings of documents of research institutes and images searched for by digital means. This cross-checking of information allowed contextual elements to be incorporated that bring to the surface the discourse behind the visual, such as those that make references to legends and urban tales. An example of this was the 
insertion of waves below the design of the Cross do Carmo, which according to legend houses an underground tunnel through which the Dutch supposedly fled after an ambush.

The icons were drawn on a single grid of 1 px per $1 \mathrm{px}$, which served as a support to reinforce the language and geometry of the representations. For each icon, three syntheses were generated: a version with the highest level of detail, a version in the scale of $1: 2$, with a lesser level of detail, and a version also in the scale of 1: 2 at a higher level of synthesis, in which elements that filled in the contours predominated. The proposal was to allow the widening of possibilities of use for each icon, which also considered possible technical limiters for application.
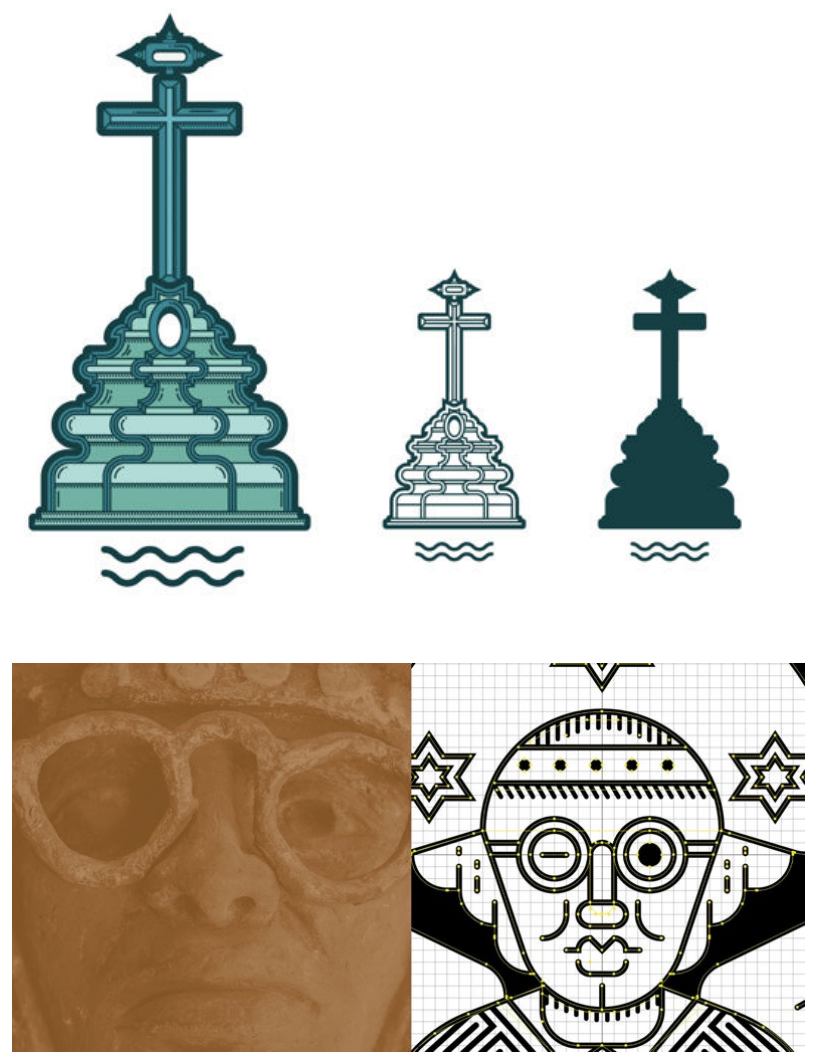

Figures 3 and 4. Graphical synthesis of the Cross of Carmo with the element of the waves and an example of the construction grid. Source: (omitted for blind review), 2016

For each category - Architectural Heritage, Natural Environment and Cultural Manifestations, a chromatic palette was defined. The composition of the chromatic palettes took as reference the colors of the references artifacts, architecture, urban and natural ambience found in the locality, in addition to the images surveyed. The tonalities of the colors were adjusted so that all palettes had the same aesthetic language.

Each category contained a set of icons, a total of 21 (twenty-one) of which Architectural Heritage (Churches, urban site and heritage buildings) had 10 icons; the Natural Environment had 05 icons and Cultural Manifestations had 06 icons.

Some icons could be broken down into graphical elements of support, as was the case of the grid of the
Cross of Carmo and the preaca $^{\text {d }}$ (Fig. 06) of Caboclinho. Having made this breakdown, a series of suggestions could be developed for application in products, signs and postcards, thus both demonstrating the possibilities of use and making the feasibility of the project evident.
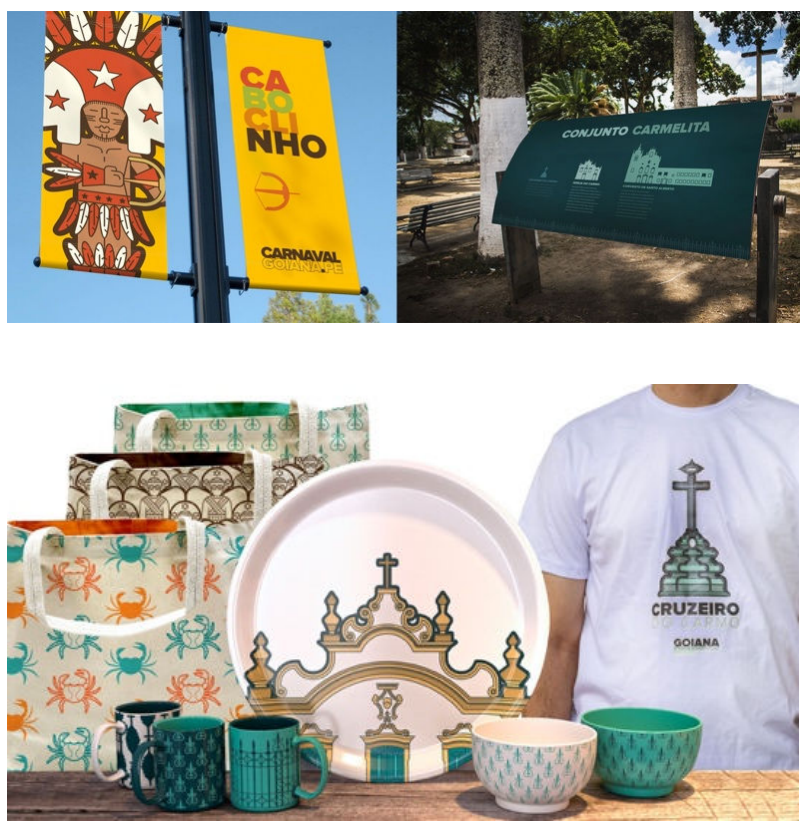

Figure 5. Suggestions for applying graphical syntheses in signposting and products. Source: (omitted for blind review), 2016

\subsubsection{Validation and Empowerment}

In continuity with the project and the participation of the local community, the set of categories, their icons and possibilities for applying them in signage, products and postcards was presented at a major meeting with representatives of the public authorities, the segments involved of the community, and the contractor and the partner. This meeting was held so that opinions could be aired and listened to and each of the icons re-evaluated. By using questionnaire techniques and group discussion. criticisms and suggestions for each of the icons could once more be incorporated into them. Moreover, this approach saw to it that the direction of the iconography project was validated, this being a process which, by its nature, is ongoing and therefore dynamic.

Using these inputs, new adjustments were made to some of the icons and other icons were incorporated, a result of the collective and participatory construction of everyone involved, whether beneficiaries or those making requests.

\section{Conclusions}

\footnotetext{
${ }^{d}$ Percussion instrument shaped like a bow and arrow used by the caboclinhos (dancers who wear Brazilian Indian dress) in the presentations of dances. (See the first image in Fig 6)
} 
The local actors who took part and collaborated in the community project worked alongside the technical staff of the project, thus facilitating the understanding of reality. Likewise, the community's perception of the value and usefulness of the project for the town, was a factor that helped to mobilize and gain the commitment of all those involved with the result. The participatory approach justified the whole effort in making arrangements to visit the town to meet people and seek information. The participatory process was a decisive factor for the quality of the results, thereby strengthening the legitimacy of the project and its appropriation.

The development of a unique and systematized graphical language contributed to strengthening the icons, thus guaranteeing a uniform reading of the project. The systematization of the language also allowed the evolution of the iconographic project which, in future, could incorporate other icons with the guarantee that the identity of the project will be maintained.

In addition, the icons which have potential for being applied in campaigns for institutional publicity, in signage of spaces and sparking inspiration as to the contents of products and services, among many other uses, will in a harmonious and consistent way contribute to communicating information about the town, which can incorporate subjective and Intangible values, which are characteristic of a creative economy, and strengthen its development.

In order to publicize the results, the possibility is being studied of Sebrae-PE publishing a catalog, which gives a detailed account of the process for developing the project, the icons and examples of the applications. Other possibilities also point to the digital distribution of the vector files for the purpose of appropriating the local community in their businesses.

Finally, the technical team found that opportunity to develop the iconographic project for the town of Goiana with the support of SebraePE and the local Town Hall, using the participatory design approach, confirmed the premises of performance of (omitted for the purposes of blind review) and at the same time prompted new questions about a designer's performance and role vis-àvis contemporary challenges.

\section{References}

BARROSO, Eduardo. Iconografia Potiguar: identidade cultural. Sebrae-RN, Natal, 2007.

BOHNSACK, Ralf. A interpretação de imagens e o método documentário. Sociologia, Porto Alegre, ano 9, junho/dezembro,2007.

CABEZA, Edilson; MOURA, Mônica; ROSSI, Dorival. Design Aberto: prática projetual para a transformação social. Strategic Design Research Journal, v.7, n.2, mai./ago. 2014

FERREIRA, Marina. Trabalho imaterial e cooperação produtiva: considerações sobre a produção em design a partir da criação das redes colaborativas. $4^{\circ}$.Congresso Sul Americano de Design de Interação. São Paulo, 2011.
FONTANA, Isabela; HEEMAN, Adriano; GOMES FERREIRA, Marcelo. Design colaborativo: fatores críticos para o sucesso do co-design. $4^{\circ}$.Congresso Sul Americano de Design de Interação. São Paulo, 2011. GAUDIO, Chiara; OLIVEIRA, Alfredo; FRANZATO, Carlo. $O$ tempo do design participativo. $11^{\circ}$ Congresso Brasileiro de Pesquisa e Desenvolvimento em Design. Gramado, 2014.

GUILHERME, Luciana. Economia Criativa Apresentação básica, Brasília:MinC.2012.

Iconografia Alagoana. Secretaria de Estado do Desenvolvimento Econômico, Energia e Logística de Alagoas- SEDEC , Serviço de Apoio a Micro e Pequenas Empresas de Alagoas- SEBRAE/AL. Maceió: GRAFMARQUES, 2011.

NEVES, Heloisa. Open Design. $8^{\circ}$ Congresso Brasileiro de Gestão de Desenvolvimento de Produto. Porto Alegre, 2011.

NIEMEYER, L. Elementos da Semiótica aplicados ao design. 2AB, Rio de Janeiro. 2009.

PIGNATARI, Décio. Informação, Linguagem, Comunicação. Ateliê Editorial: São Paulo, 2003.

PEIRCE, Charles S. Semiótica. São Paulo: Perspectiva, 1999.

PIIRAINEM, Kalle; KOLFSCHOTEN; LUKOSCH, Stephan. Unraveling challenges in collaborative design. A Literature Study. $15^{\text {th }}$ International Conference on Groupware: design, implementation and use. London/UK, 2009.

SANDERS, E; STAPPERS, P J. Co-creation and the new landscapes of design, 2008. Available at: http://www.maketools.com/articles-

papers/cocreation_sanders_stappers 08 preprint.pdf.

Accessed on 20 April 2016.

SEBRAE PE; Laboratório de Design O Imaginário da UFPE, Iconografia de Goiana, forthcoming publication. DEL GAUDIO, Chiara. Design Participativo e Inovação Social: a influência dos fatores contextuais. 2014 Tese de doutorado - Pontífice Universidade Católica - Rio, Programa de Pós-Graduação em Design. 